\title{
INSURANCE AND INCENTIVES IN SHARECROPPING
}

\author{
LUIS H. B. BRAIDO
}

\author{
CESIFO WORKING PAPER NO. 1098 \\ CATEGORY 10: EMPIRICAL AND THEORETICAL METHODS \\ DECEMBER 2003
}

Presented at Venice Summer Institute, Workshop on Insurance, July 2003

\footnotetext{
An electronic version of the paper may be downloaded

- from the SSRN website: www.SSRN.com

- from the CESifo website: www.CESifo.de
} 


\title{
INSURANCE AND INCENTIVES IN SHARECROPPING
}

\begin{abstract} summary discussing some important policy implications.

JEL Classification: C52, D82, O12, Q15.

\author{
Luis H. B. Braido \\ Graduate School of Economics \\ Getulio Vargas Foundation \\ Praia de Botafogo 190, s. 1100 \\ Rio de Janeiro, RJ 22253-900 \\ Brazil \\ lbraido@fgv.br
}

This essay surveys some recent empirical works about sharecropping. The basic theoretical trade-offs are discussed in the introduction. Section 1 discusses the empirical research on resource allocation. This section is divided in two subsections: one studying the effects of tenure stability on land improvements, and another comparing the impact of different share rates on input use and farm productivity. Section 2 surveys works testing different arguments raised to explain the design of tenancy contracts. The essay then concludes with a brief

This essay was written for the 2003 Venice Summer Institute. Comments and additional references are welcome. I wish to thank Helena S. Perrone for excellent research assistance. Her efforts and comments are reflected throughout this essay. I am solely responsible for all errors and omissions. 
"To the slave cultivators of ancient times, gradually succeeded a species of farmers know at present in France by the name of Metayers." "It could never, however, be to the interest even of this last species of cultivators to lay out, in further improvement of the land, any part of the little stock which they might save from their own share of the produce, because the lord, who laid out nothing, was to get one-half of whatever is produced." (Adam Smith, 1776, vol. I, pp. 412 and 414)

"With a short-term lease (sharecropping) renters are obviously aware that landlords have the alternative of renting their land for a cash rent independent of current output. Consequently, the tenant must plan to produce an average output per acre that will provide a rental payment, if yields are average, equal to the possible cash rent plus any additional payment required to compensate the landlord for the uncertainty that he bears." "Once he has found a farm, he may fear that his lease will not be renewed unless sufficient rent is actually paid." (D. Gale Johnson, 1950, pp. I 20)

Insurance is the term used to describe formal and informal arrangements aimed at dealing with the risk of harmful events. Risk has been a main concern of the human race since early times and many practices in primitive tribes can be seen as insurance mechanisms. This essay is intended to survey some recent empirical works about sharecropping - a very old type of insurance used to share the risk posed by nature on agricultural activities.

Sharecropping (or Metayer System) is a form of land leasing in which a tenant and a landlord share the output of a farm as compensation for the managerial 
labor supplied by the former and the land capital supplied by the latter. This type of leasing has been used since ancient times and is still important in modern economies. ${ }^{1}$ As the initial quotes suggest, the debate about sharecropping is classical and still active in modern economics.

Agriculture has been seen as a major element in economic thought since the Physiocrats. However, Adam Smith was the first classical author to explicitly comment on the sharecropping practice. In the first volume of the Wealth of Nations (Book II, Chapter II), Smith discussed the discouragement of agriculture and strongly stresses the lack of incentives inherent to the metayer system. Sharecroppers bear alone most of the input costs (especially labor costs) and receive only fraction of the final output. As a consequence, they would tend to undersupply these inputs. Furthermore, they face high tenure uncertainty, which reduces their incentives to promote land improvements.

Based on similar arguments, many other classical authors condemned this type of lease. John Stuart Mill (1848) wrote: "The metayer has less motive to exertion than the peasant proprietor, since only half the fruits of his industry, instead of a whole, are his own." 2 The fact that different generations of the same family live as tenants on some lands is also mentioned as able to reduce the problems caused by tenure uncertainty. ${ }^{3}$ Alfred Marshall (1890) shared the view of previous authors. He wrote: "For, when the cultivator has to give to his landlord half of the returns to each dose of capital and labor that he applies to the land, it will not be to his interest to apply any doses the total return to which is less than twice enough to reward him." ${ }^{4}$ Karl Marx (1894) condemned sharecropping, considering it a feudal institution incompatible with capitalism. ${ }^{5}$

In spite of the apparent consensus among the classical economists against sharecropping, this type of lease remained in use throughout the Old World and became even more popular in the New World. Intriguing, share contracts in the 20th cen-

\footnotetext{
${ }^{1}$ Hodkinson (1992) comments on the sharecropping practice in ancient Greece. Hoffman (1984) mentions a dramatic expansion of sharecropping in France between the Middle Ages and the 17th century. He suggests that most French historians blame it for increasing social stratification and poverty in the countryside. Ackerberg and Botticini (2002) present an analysis of the risk-sharing properties of sharecropping in early Renaissance Tuscany.

${ }^{2}$ Mill (1848), Book II, Chapter VIII, pp. 304.

${ }^{3}$ Mill also mentions the very critical view of the English writers (Arthur Young, Mr. M'Culloch, Mr. Jones, Turgot, and Destutt-Tracy), and acknowledges the view of M. de Sismondi (a landowner from Tuscany) defending the metayer system for protecting tenants from land disputes with their neighbors - such disputes would be part of the landlord's responsibilities.

${ }^{4}$ Marshall (1980), Book VI, Chapter IX, pp. 644.

${ }^{5}$ This is a curious point. In fact, the idea of a noble landlord leasing lands to poor farmers in order to avoid being involved in productive actives does not seem to fit in a dynamic capitalist system. However, the idea of an absentee shareholder hiring a manager to run a company turned out to be a main characteristic of modern capitalism.
} 
tury tended to have short duration, contrary to the classical arguments for tenure stability. Noticing this fact, D. Gale Johnson (1950) stressed that by granting short-term leases, the landlord keeps the possibility of using renovation threats as an extra source of incentives. Moving is costly for tenants, and landlords tend to renew contracts based on relative performance (i.e., by comparing the productivity of sharecropped farms with those of similar lands owned or leased under fixed rent). Hence, this repeated feature of tenancy contracts should induce sharecropping tenants to supply the appropriate amount of labor and other inputs. Moreover, the landlord should be willing to pay for land-specific investments, which alter the longterm productivity of the land and, therefore, its rental price. Under these premises, sharecropping generates no loss of efficiency in resource allocation.

\section{Modern Theory}

From Adam Smith to D. Gale Johnson, the debate was mainly concentrated on the sharecropping incentives for proper allocation of resources. Cheung (1969) shifted the focus of the discussion towards the insurance properties of sharecropping. He argued that efficient resource allocation would be obtained whenever landlords were able to monitor tenants' activities. Under this premise, sharecropping is presented as an efficient way of sharing the production risk between landlords and tenants. In equilibrium, the share of risk borne by landlords and tenants would be determined by the difference in their level of risk aversion.

In 1974, Joseph E. Stiglitz published a distinguished analysis of the sharecropping problem. Share contracts were viewed as an optimal solution for an insurance problem in a scenario with moral hazard. Tenants usually choose privately observed variables that affect productivity, and the optimal share rate should balance the incentives for exerting these hidden actions and the costs of risk bearing. The works by Stiglitz (1974), Holmstrom (1979), Grossman and Hart (1983), Holmstrom and Milgrom (1987), among others, showed that the optimal tenancy contract should not provide full incentives for tenants in environments with moral hazard. Similar to the predictions of Adam Smith and other classical authors, sharecropping would in fact not induce the maximum output per unit of land. However, this productivity loss would be compensated by the welfare gains of sharing risk.

By connecting the early discussion about resource allocation with Cheung's analysis of optimal contract design, the literature on moral hazard set the basis for our modern understanding of tenancy contracts. This literature together with the works on asymmetric information developed by Akerlof (1970), Spence (1973), and Rothschild and Stiglitz (1976) became the core of modern insurance theory.

Insurance, however, is not the only motive raised in the literature to explain the design of tenancy contracts. Rao (1971) and Prendergast (2002) argue that the value of managerial effort and entrepreneurial activities is much higher in risky envi- 
ronments. Gains associated with delegation of decision-making power are increasing with risk and, thus, risky farms would be rented under contracts with high incentive power (i.e., contracts in which a high share of the output is retained by the tenant). This prediction is in sharp contrast with those based on insurance. In a different vein, papers on transaction costs list a number of different features that can affect the contract choice. For instance, costs for measuring the final output tend to disencourage share contracts (see Allen and Lueck, 1992). Also, negotiations to determine the rental price in a fixed-rent contract can destroy trust between the parties since, usually, landlords have better information about the land (see Williamson, 1979 and Murrell, 1983).

New aspects of the agency problem have been pointed out recently. Eswaran and Kotwal (1985) discuss a situation in which the landlord also exerts productive activities. In this scenario, sharecropping would not only share the risk between the two parties, but also provide incentives for both of them. Laffont and Matoussi (1995) stress that, when dealing with a poor and credit-constrained tenant, sharing the output might be the only way a landlord has to extract the tenant's surplus. Prizes based on relative performance were studied by Lazear and Rosen (1981) and Green and Stokey (1983). Lambert (1983) and Rogerson (1985) show that the optimal finite-horizon dynamic contract is history dependent and provides intertemporal insurance for the agents, but also imposes some risk on them within each period, similarly to Holmstrom (1979). Furthermore, infinite-horizon versions of the moral hazard model were shown to be able to replicate the arguments for first-best efficiency of sharecropping. Rubinstein and Yaari (1983), Radner (1981, 1985), Spear and Srivastava (1987), among others, study the infinitely repeated version of the principal-agent relationship and show that the first-best solution would be approximately achievable.

All these theoretical advances have raised the sophistication level of the debate about sharecropping, making empirical investigation even more crucial to test the relevance of each different argument. Recently, the availability of well-built databases as well as the development of new identification strategies have brought some light to the debate. This essay discusses some of these recent contributions without intending to be representative of the entire literature (which is probably an impossible task). Other complementary surveys are found in Binswanger, Deininger, and Feder (1995) and Deininger and Feder (1997).

The remainder of this work is organized as follows. Section 1 discusses the empirical research on resource allocation. This section is divided in two subsections: one studying the effects of tenure stability on land improvements, and another comparing the impact of different share rates on input use and farm productivity. Section 2 surveys works testing different arguments raised to explain the design of tenancy contracts. The essay then concludes with a brief summary discussing some impor- 
tant policy implications.

\section{Resource Allocation}

The two main features of tenancy contracts are tenure status and incentive power (i.e., the share of the final output received by the tenant). Since sharecropping and fixed-rent tenants face tenure uncertainty, fear of expropriation would lead them to make suboptimal levels of long-run investments. However, these investments should be promoted by landlords, who benefit from their long-run impacts on the lands (unless they depend on some unobserved action exerted by the tenant, such as land care). The first subsection aims to present empirical papers addressing this topic.

Incentive power, on the other hand, would have systematic impacts on land productivity and input use. Share contracts display lower incentive power than ownership and fixed-rent contracts. In the absence of other incentives (such as renovation threats), farmers under share contracts would use a lower amount of each noncontractible input (whose costs are not shared by the landlord) and, thus, their farms would be less productive. Subsection 1.2 addresses this issue.

\section{$1.1 \quad$ Tenure Status}

The review here begins with the paper by Besley (1995), which studies the relation between land-specific investments and property rights in Ghana. The results support the hypothesis that land rights and investments are positively correlated. This finding is indirectly related to tenure status, since like better-defined property rights, tenure stability avoids expropriation of long-run investments. The second paper discussed, Banerjee, Gertler, and Ghatak (2002), uses a very unique quasiexperiment to study the effect of land tenure on resource allocation. This is a very special paper that links tenure status to incentive power (thus also related to the topic of the next subsection). The authors use an exogenous change in property rights in West Bengal that increased tenure stability of tenants and, subsequently, increased the incentive power of tenancy contracts and land productivity. Next, Jacoby and Mansuri (2002) suggest that, in Pakistan, owned lands tend to receive more specific investments than leased lands; and Bandiera (2002) shows that Nicaraguan farmers are more likely to grow trees in combination with annual crops in their owned lands (as opposed to leased lands).

\section{Besley, J.P.E., 1995}

This work examines the correlation between investment and land rights in Ghana. The author list three possible channels driving this correlation. First, land rights would affect investments through fear of expropriation. Also, better-defined land 
rights may facilitate land being collateralized, reducing interest rates faced by landowners and, then, increasing land investments. Finally, there is a link between investment and land rights through gains from trade. Superior land rights increase the extent of the land market for selling and renting. This amplifies the effects of new investments on the lands' prices and rents, increasing the incentives to invest.

The empirical analysis is based on farm-level data from two regions of Ghana, namely Wassa and Anloga. The main product grown in Wassa is cocoa and the only significant investment made to improve the land is planting tree crops. In Anloga, most agriculture is devoted to growing shallots (a type of small green onion) and land improvements are much more diverse than in Wassa. The database contains: (i) information on land and household characteristics; (ii) a binary variable indicating whether land investments were made or not; and (iii) discrete variables describing household rights on each operated field. There is significant variation in property rights as a consequence of Ghana's transition from a traditional system (where land ownership was communal and controlled by a tribal chief) to a more modern system that emphasizes individual claims. These rights fall into twelve categories: rights to sell, rent, gift, mortgage, pledge, and bequeath, each of them with or without lineage approval. In many parts of the paper, property rights are aggregated in two categories: number of rights with and without need for approval.

The author starts by investigating the relationship between investment and land rights by means of a discrete choice model. Estimations are conducted with and without household fixed effects. ${ }^{6}$ A number of variables describing the mode of acquisition of each farm (purchased, appropriated, gifted, etc.) and the number of years since the acquisition are used as instrumental variables for property rights. The results for Wassa indicate that land rights do influence investment: better rights significantly raise the probability of land investments. The results for Anloga are less robust, but still broadly in line with the theory.

Extensions attempt to access which of the channels previously listed drive this relationship. In such extensions, the author makes use of the disaggregated definition of household rights. First, under the collateral-based argument, differences between rights that are specific to a particular field and those that are enjoyed by the farmer in all fields operated. Being allowed to use a particular field as collateral does not necessarily imply that the investments should occur on that specific field. Thus, if the relationship between investments and land rights were driven by the effects of property rights on access to credit markets, investments should be related to rights enjoyed in all fields, rather than field-specific rights. Next, under the gainsfrom-trade argument, some land rights (such as the right to sell or rent the field)

\footnotetext{
${ }^{6}$ Household fixed effects account for farmer heterogeneity, but rule out the identification of effects that depend on the average rights (as in the collateral-based theory).
} 
should have a greater impact on investments than other rights (such as the right to mortgage, for instance). The results do not strongly support any of these two particular theoretical views. In general, the results based on the disaggregated measures of rights are not as robust as the previous ones.

Banerjee, Gertler, and Ghatak, J.P.E., 2002

In the late seventies, there was a major change in property rights in West Bengal, India, due to a reform of tenancy laws known as Operation Barga. The reform, carried out by a newly elected left-wing administration, increased tenants' bargaining power and secured tenure to the land. The election of this new administration in West Bengal is interpreted by the authors as a national response to the party in power, which had ruled India since its independence, rather than a local particularity. Operation Barga is thus interpreted as an exogenous change in property rights and used to examine the relationship between tenancy laws and efficiency.

The paper first develops theoretical models for the landlord-tenant relationship, based on moral hazard and limited wealth of tenants, which are then used to analyze the potential effects of the reform on the contractual relationships. The reform increased tenants' reservation utility, since they could not be evicted by the landlord anymore and they could choose to retain the share of the output accorded before the reform. Due to limited liability, a higher outside option increases the optimal share rate retained by the tenant. The authors bring evidence showing that, in fact, the incentive power of tenancy contracts has increased after the reform. Greater tenure security and a higher share rate induce the tenant to increase the supply of effort and noncontractible land-specific investments. On the other hand, after the reform the landlord loses the possibility of using the threat of eviction as a credible incentive device.

The effect of Operation Barga on productivity was estimated using two approaches. The first is a quasi-experiment that uses Bangladesh as a control. The authors argue that Bangladesh may be used as a control because: (i) it did not introduce tenancy reform; (ii) it is very similar to West Bengal in terms of agroclimatic conditions, prevalence of tenancy, and agricultural technology; (iii) it had growth rates similar to West Bengal during the period before the reform. The second approach compares the productivity growth in districts in which Operation Barga was implemented intensively to districts in which the program was implemented less intensively. ${ }^{7}$ The results from both approaches indicates a positive impact of Operation Barga on sharecropping productivity.

\footnotetext{
${ }^{7}$ Intensity is measured by the number of sharecroppers who registered with the Department of Land Revenue (a necessary condition for the tenant to be entitled to permanent and inheritable land tenure).
} 


\section{Jacoby and Mansuri, Mimeo, 2002}

Using data from the Pakistan Rural Household Survey completed in 2001, Jacoby and Mansuri (2002) study whether farmers tend to invest more in their own lands than in the lands they lease (under sharecropping and fixed rent). Land-specific investment is measured by the amount of farmyard manure (FYM) used per acre cultivated during the year. The authors argue that: (i) FYM improves land quality and its effects last for many seasons; (ii) FYM is not portable once incorporated into the soil; (iii) FYM is usually collected as a byproduct of farmers' own livestock and manuring is very labor intensive. Thus, under imperfect monitoring, farmyard manure could be interpreted a noncontractible land-specific investment.

The database contains a subsample of mixed tenants (i.e., households that cultivate owned and leased lands). This feature permits the comparison of investment behaviors across plots of the same household, avoiding potential biases caused by unobserved characteristics of the tenant. In addition to this, one must also worry about selection bias caused by soil-quality heterogeneity. The authors use differences between landholding of the mixed tenant and his landlord in each leased field as an instrument for differences in soil quality. The instrumental variable captures particular characteristics of the landlord that would be correlated with soil quality and uncorrelated with unobserved aspects of FYM investments (the dependent variable), as far as landlords did not affect investment decisions in their leased plots. The results indicate that FYM investments are lower on leased (as opposed to owned) lands cultivated by the same household, which supports the existence of a holdup problem.

\section{Bandiera, Mimeo, 2002}

Cultivation of trees in combination with regular crops is costly, but conserves soil fertility and reduces soil erosion (a benefit not fully appropriated by untenured tenants). Bandiera (2002) analyzes the dichotomous choice of farmers who may or may not grow trees, using data from the 1998 Nicaragua Living Standards Measurement Survey matched with town data from the 1995 Nicaragua Census.

After using the full cross-sectional sample, the author uses information on farmers who own and rent different plots in order to control for non-random heterogeneity in household characteristics. Land characteristics are not available. Potential selection bias caused by heterogeneous land quality is addressed through a variable indicating if a particular owned farm was originally acquired via land reform (rather than purchase or inheritance). Owned lands acquired via land reform were originally leased before the reform, being thus similar to currently leased farms.

The results indicate that owned lands are more likely to have trees together with annual crops. However, one must be careful when interpreting this evidence. Trees are probably observable by landlords, and the fact that landlords choose not 
to enforce their cultivation might not be related to tenure.

The author also finds that the tenant's wealth is not a significant determinant of technique choice, which suggests that limited liability and risk sharing are not crucial aspects of the tree-growing decision.

\subsection{Incentive Power}

This subsection studies the effects of incentive power on input use and farm productivity. It starts with the paper by Rao (1971), which contains an investigation of the productivity difference between owner-operated and share-rented farms in India. The results are not conclusive. Owner-operated farms produce more output per acre, but sharecroppers are more productive than owners when farm-size level is held constant. In another classical work, Shaban (1987) uses data from the International Crops Research Institute for Semi-Arid Tropics (ICRISAT), in India, to study differences in resource allocation across owned and sharecropped lands cultivated by the same farmer. He finds that farmers are more productive and use inputs more intensively on their own lands, suggesting existence of incentive problems. Next, Laffont and Matoussi (1995) theorize that, under limited liability, poor sharecroppers would tend to retain a lower fraction of the output and, thus, exert less effort and be less productive. They bring evidence from Tunisia confirming their theory.

The last work presented here, Braido (2003a), suggests that the incentive problems measured by comparing land productivity and input use across farms under different contracts can be biased by land-quality heterogeneity. In situations where land quality is not randomly distributed across different contracts, one must be careful when interpreting differences in input use and output produced per unit of land. Typically, tenants cultivate lands with lower value, which directly reduces their productivity as well as the marginal return of investing in each factor. Hence, the fact that sharecroppers are less productive and employ a lower amount of each input need not mean the existence of shirking behavior. This paper uses ICRISAT data to revisit Shaban's conclusions under this new perspective. The results pose some questions on the belief that sharecroppers shirk systematically.

An important remark must be made here. Except for Laffont and Matoussi (1995), the papers discussed in this subsection do not have data on the tenure status or the length of different contracts. An implicit assumption of these papers is that long-term incentives do not affect short-term productivity.

It is worth stressing that I opted to discuss Banerjee, Gertler, and Ghatak (2002) in Section 1.1, but this paper is also related to incentive power. The productivity increase that followed the land reform in West Bengal is due to a combination of two effects: tenure stability and higher incentive power. The reform guaranteed tenure stability, reducing holdup problems associated with long-run investments. It 
also improved tenants' bargaining power, which increased the share rate retained by tenants due to limited liability.

\section{Rao, J.P.E., 1971 - Part I}

An important part of Rao's paper refers to optimal contract design and, then, it is left for Section 2. Here, I present another investigation carried in that paper (pp. 588 ) testing the average productivity difference between owner-operated and sharerented farms. The work uses farm-level data from the Studies in Economics of Farm Management, in India. In this part of the paper, the author uses 137 observations from two different cropping years, 1957-58 and 1958-59, in ten different villages (seven of them in the rice zone and three in the tobacco zone).

The author argues that land quality (measured by imputed values of land resources) and other inputs are highly correlated. Hence, he estimates a Cobb-Douglas production function where land quality is the only independent variable (capturing the joint effect of land quality and other inputs).

The results are ambiguous. Output per acre is higher in the owner-operated fields than in share-rented farms, but observed land quality explains around 90 percent of this variation. Moreover, the elasticity coefficients indicate the existence of diminishing marginal productivity among owner-operated plots and constant marginal productivity under sharecropping. Thus, Rao estimates the effect of the contract on the average per acre output at each farm-size level. Unlike before, the productivity is higher in sharecropped lands than in owner-operated farms of corresponding sizes.

\section{Shaban, J.P.E., 1987}

This work tests between two theoretical models of sharecropping: the Marshallian approach versus Cheung's monitoring approach. The Marshallian approach assumes a prohibitively high cost of monitoring the tenant's activities. Non-monitored farmers tend to use less inputs in their sharecropped lands relatively to their owned lands. Consequently, this leads to a lower output per acre in sharecropped farms. The monitoring approach, on the other hand, theorizes that if landlords accessed an effective and inexpensive monitoring technology, they would stipulate all relevant actions to be followed by tenants. In this scenario, there would be no misallocation associated with sharecropping.

The empirical investigation uses farm-level data from the ICRISAT's Village Level Studies, which contain detailed farming information from eight villages in India. The database contains a subsample of sharecroppers who simultaneously own and sharecrop different fields, allowing one to control for household heterogeneity. Shaban compares the average per acre output and per acre inputs in owned and sharecropped lands of the same household. He claims that higher output and input intensities on owned land would support the Marshallian approach, while equal 
estimates for owned and sharecropped lands would favor Cheung's monitoring approach.

The results indicate significant differences between per acre output and input intensities on owned and sharecropped plots of the same household. Controlling for variations in irrigation, plot value, and some observed soil characteristics, one finds that the output per acre is higher by 16.3 percent on owned relative to sharecropped lands of the same household. Farmers also use significantly more input on each acre of their owned farms.

\section{Laffont and Matoussi, RAND, 1995 - Part I}

This paper develops a stylized model of sharecropping with the objective of explaining contracts observed in El Oulja, a rural area of Tunisia. They key aspect of the model is the presence of ex ante financial constraints that limit the tenants ability to pay up front rents and invest in productive inputs. Thus, fixed-rent contracts, which induce appropriate levels of effort, might not be feasible for landlords dealing with poor tenants. In their theory, share contracts have the function of providing effort incentives and solving financial constraints. They show that the share of the product retained by the tenant, the level of effort exerted, and the output produced are all decreasing in the tenant's working capital.

These predictions are tested using data collected with the help of the Tunisian National Institute of Statistics in 1986 in the rural area of El Oulja, Tunisia. The empirical part can be divided in two subparts: one studying productivity across contracts and another investigating the determinants of contract designs. Here I focus on the productivity discussion, leaving for Section 2 the part on contract choice.

The database contains information on general characteristics of 100 families (including wealth and income) and detailed farming information on each plot operated by these families (including plot size, type of crop, tenancy status, and production and input levels). A later data collection was carried out in 1988 but, since the authors do not seem to trust these more recent data, they are used only to test the robustness of the results.

The authors estimate a log-linear production function using output per hectare as the dependent variable and dummy variables for the tenancy contract (fixed rent or sharecropping), hired labor, family labor, and other inputs (evaluated per hectare) as control variables. They acknowledge the fact that the tenancy status is endogenous and attempt to solve potential endogeneity biases by means of instrumental variables. They claim that the types of crop (e.g., tomato, potato, melon, vegetable) are good instruments for the tenancy contract. For that to be true, the type of crop should be correlated to the tenancy contract and not related to unobserved features affecting output. The IV estimates for the contract-dummies coefficients are similar 
(namely, 4.8 for fixed rent and 4.4 for sharecropping - see pp. 391), but statistically different from each other. Since the contract-dummies coefficients measure the impact of each contract on expected output, this result suggests that sharecroppers exert less effort than fixed-rent tenants. It is also found that, in sharecropped fields, productivity is positively related to the length of the relationship.

\section{Braido, Mimeo, 2003a}

Land characteristics vary considerably across farms under different tenancy status. Typically, lands leased out to tenants (under sharecropping or fixed rent) have lower quality than those cultivated by the owners. Some authors argue that good lands are cultivated by owners because they display larger scope for soil exploitation (see Allen and Lueck, 1992 and 1993, and Dubois, 2002).

Most of the literature on incentive power compares the amount of different inputs used and output produced (evaluated per unit of land) across fields under different contracts. However, in the presence of land heterogeneity, comparing quantities (or values) is not a valid procedure to test existence of incentive problems. It is usually optimal to use inputs less intensively on lands with lower quality, and this relationship is not necessarily linear (as assumed by Shaban, 1987) or log-linear (as assumed by Rao, 1971). Furthermore, many land characteristics are privately observed and, thus, not available in the databases. Thus, whenever sharecropping is associated with lower-quality lands, these farms will naturally employ inputs less intensively and be less productive (even after controlling linearly or log-linearly for observed land characteristics).

Braido (2003a) acknowledges this fact and accesses ICRISAT's Village Level Studies (India) to revisit the incentive-power analysis under this perspective. In order to better illustrate the main point of this paper, consider the following CobbDouglas production function:

$$
y_{i}=A_{i} k_{i}^{\alpha} \exp \left(\varepsilon_{i}\right),
$$

where $i$ indexes the plot in a certain year and season, $y_{i}$ represent the output produced per unit of land; $A_{i}$ is a productivity factor related to observed and unobserved land quality; $k_{i}$ represents all inputs used per unit of land; and $\varepsilon_{i}$ is an error term accounting for hidden actions (such as managerial effort) and other shocks.

Define $\theta_{i}=E\left(\frac{p}{r} \exp \left(\varepsilon_{i}\right) \mid \mathcal{I}_{i}\right)$, where $p$ and $r$ represent (respectively) the prices for $y_{i}$ and $k_{i}$, and $\mathcal{I}_{i}$ is the information set available for the farmer cultivating plot $i$. Notice that $\theta_{i}$ is not constant across plots due to differentiated information about prices and shocks.

For general production functions, profit-maximization conditions establish an implicit relationship between $k_{i}$ and $A_{i}$. For the Cobb-Douglas, this relationship is explicitly given by: 


$$
k_{i}=\left(\alpha A_{i} \theta_{i}\right)^{\frac{1}{1-\alpha}} .
$$

A few important features are worth noticing from (2). First, lower land quality $\left(A_{i}\right)$ implies lower input use and, thus, lower output per unit of land. Second, even minor differences in land quality $\left(A_{i}\right)$ may significantly impact productivity $\left(y_{i}\right)$, since this effect is amplified through input choices.

Assuming Cobb-Douglas technology and profit maximizing behavior, one must notice that $\ln \left(k_{i}\right)$ and $\ln \left(A_{i}\right)$ would be colinear if and only if $\theta_{i}$ were constant across plots (i.e., $\theta_{i}=\theta$ ). If besides that the productivity factor $A_{i}$ were perfectly observed, then one could ignore inputs when estimating the reduced form of (1). However, there are reasons for $\theta_{i}$ to vary across plots and (more seriously) $A_{i}$ is not perfectly measured, so that ignoring inputs $\left(k_{i}\right)$ introduces a serious problems in the estimation of (1).

The paper then proceeds in the following manner. First, it tests the effect of the contract form on productivity when observed land quality and input choices are used as controls. The results show that the entire productivity gap across contracts is explained by differences in input use. This could be due to the fact that tenants shirk in their input choices or that these choices reflect land-quality heterogeneity. One must then test whether input choices were distorted.

If inputs were optimally chosen, the marginal productivity of each factor should be the same across farms under different tenancy contracts, regardless of the distribution of land quality. A test procedure is developed by using the fact that, when the production function is Cobb-Douglas, the marginal productivity is easily measured by $\alpha \frac{y_{i}}{k_{i}}$. The tests conducted cannot reject the hypothesis that marginal productivities of labor and nonlabor inputs are constant across plots under ownership, fixed rent, and sharecropping.

\section{Contract Design}

This section reviews the debate on the designs of tenancy contracts. The two main characteristics of tenancy contracts are, again, contract length and incentive power. The literature however is mainly focused on the latter topic, and Bandiera (2001) is the only paper discussed here that explicitly addresses the first issue.

Regarding incentive power, there are three different classes of arguments commonly used to explain it. First, the agency theory (see Holmstrom and Milgrom, 1987) stresses the trade-off between incentives and risk. Holding agents' risk aversion constant, high-powered contracts were expected to appear in fields with lower exogenous risk. On the other hand, the delegation theory (see Rao, 1971 and Predengast, 2002) predicts exactly the opposite: since the scope for entrepreneurship 
is higher in high-risk fields, incentives are also more important in these farms. Finally, arguments based on transaction costs predict that crops with lower costs for monitoring effort and for measuring inputs and the final output are more likely to be rented under sharecropping.

The review is presented chronologically. It starts with the part of Rao (1971) that was purposely omitted in Section 1. Rao finds a positive association between farm risk and incentive power, supporting the delegation theory. Next, three papers on transaction costs are discussed: Hoffman (1984) suggests that vine plots are usually rented under sharecropping due to lower costs of monitoring the tenant; Allen and Lueck (1992) stress aspects related to soil exploitation and costs of measuring the final output as important in explaining tenancy contracts; and Allen and Lueck (1993) associate costs of measuring inputs with share contracts in which landlords and tenants also share input costs. I then discuss a small part of Laffont and Matoussi (1995), showing that incentive power is affected by the tenant's working capital but not by the tenant's wealth, emphasizing the relative importance of financial constraints over insurance motives to explain contract designs. Unlike this finding, Ackerberg and Botticini (2002) find that the contract power is positively affected by the tenant's wealth in Renaissance Tuscany. Dubois (2002) studies how share contracts dynamically balance risk-sharing, effort incentives, and incentives for land-quality maintenance. Finally, some recent working papers by Bandiera (2001), Pandey (2001), and Braido (2003b) are presented.

\section{Rao, J.P.E., 1971 - Part II}

Let us discuss now another part of Rao's (1971) paper, related to contract design, which was deliberately ignored in Section 1. The argument developed by the author is based on the idea tenants exert a variety of different entrepreneurial functions. Fixed-rent contracts permit the tenant to capture the returns associated with decision making and protect the landlord against possible risk arising from the production decisions of the tenant. Hence, these contracts should be observed in environments with high risk and significant scope for entrepreneurship. On the other hand, in low-risk scenarios, where the scope for entrepreneurial decisions is restricted, sharecropping arrangements insure tenants against risk.

This theory is tested against data from the Studies in Economics of Farm Management collected by the Government of India in three different years, 1957-58, 1958-59, and 1959-60, in seven villages of the rice zone and three of the tobacco zone. Sharecropping and fixed rent coexist in the villages studied, the first being predominant in the rice zone and the latter being more common in the tobacco zone. The estimated variance of profits is much higher for the tobacco zone (where fixed rent is predominant) than for the rice zone (where sharecropping is predominant). Furthermore, irrigation pattern, variation in rainfall, and variation in prices also 
suggest tobacco as a riskier culture than rice. Hence, scope for entrepreneurship rather than risk sharing is viewed as the key element explaining the design of share contracts.

\section{Hoffman, J. Econ. History, 1984}

In this work, the author argues that, due to costs of supervising the tenant, landlords are more likely to lease distant lands under higher-powered contracts. Moreover, crops requiring a close landlord are more likely to be rented under lowerpowered contracts. These predictions are tested against historical data from 83 contracts, dated between 1533-1633 in France.

Logit estimations show that distant lands are more likely to be rented under fixed rent relatively to sharecropping, and to sharecropping relative to wage labor (confirming the first theoretical prediction). Moreover, vines are more likely to use wage labor than tenancy and, among the fields leased, sharecropping is more common than fixed rent. The author argues that vines require present landlords regardless of the tenancy contract. Considerable damage could be caused if the tenant neglected buildings and fences. Moreover, by cutting the vines very short, one increases return in that season at the cost of reducing productivity thereafter. Hence, the cost of monitoring farming activities is significantly lower in vines and the fact that these lands are leased under lower-powered contracts support the second theoretical prediction.

\section{Allen and Lueck, J. Law \& Econ., 1992}

Due to tenure uncertainty, tenants have incentives to overuse the land. Sharecropping alleviates this distortion relative to fixed rent because sharing the output reduces the tenant's gains in overusing the land. However, in order to implement share contracts, the landlord must incur the costs of measuring the final output.

This is the basic trade-off studied by Allen and Lueck (1992). Under this theory, sharecropping is expected to occur in environments with high possibilities for soil exploitation and where the cost of dividing the output is low. The authors test this prediction using a sample with 3,432 leasing contracts from the 1986 Nebraska and Sough Dakota Leasing Survey. Measurement costs are proxied by the type of crop cultivated. Hay crops are more difficult to measure, since they are typically sold through private sales in contrast to other cultures that are publicly sold at local elevators. Scope for soil exploitation is measured by proximity to urban areas and presence of irrigation. Proximity to urban areas provides alternative uses for the land, making concerns about soil exploitation less important. Irrigation makes soil exploitation less likely. Thus, proximity to urban areas and irrigation should be positively correlated to fixed rent.

A logit analysis is conducted and the results support the underlying theory. In 
addition, the authors find that sharecropping is positively related to corn and wheat. Since corn is a crop with high profit variability and wheat is a low-risk culture, the author argues that this evidence does not support the risk-sharing motives commonly associated with sharecropping.

\section{Allen and Lueck, RAND, 1993}

Here, the analysis of the previous paper is extended to understand not only the share rate used to divide output, but also the share of input costs borne by the landlord. Agricultural production depends on land and productive inputs. Assuming a production function that is separable in each factor, fixed rent induces proper use of inputs. However, since the opportunity cost of using the land is typically lower for untenured tenants as opposed to owners, fixed-rent contracts induce land overuse. Sharecropping, on the other hand, alleviates the incentives for land overuse, but implies costs of measuring the output. Share contracts also distort incentives for proper use of other inputs, but this could be solved by sharing input costs between landlords and tenants at the same rate used to share the output.

In this setup, one should expect sharecropping to be associated with lower costs of measuring output and high possibilities for soil exploitation. Moreover, for easily measured inputs, sharecropping landlords would share costs at a rate equal to the crop-share rate. Finally, fixed-rent contracts would be associated with environments with few possibilities for soil exploitation and high measurement costs.

These predictions are tested using data from the 1986 Nebraska and South Dakota Land Leasing Survey. Evidence shows that, in general, tenants either bear input costs alone or share them with the landlord at the same rate as the output share. Tenants retain a higher share of the output when they bear input costs alone.

Moreover, logit estimates show that inputs purchased in the market are more likely to be shared than those provided by the farmer (i.e., those harder to measure). The probability of having an input being shared is negatively affected by the land's value, which proxies for scope of soil exploitation, and by the fraction of the total area cropped under the current contract - the more lands from the same landlord, the lower the tenant's ability to shirk on the use of shared inputs.

\section{Laffont and Matoussi, RAND, 1995 — Part II}

This paper has multiple aims, some of them already discussed in Section 1. Here, I focus on a small part of it (pp. 395-397), which uses a ordered probit model to study the selection of contracts. Evidence from El Oulja, in Tunisia, shows that incentive power is negatively related to the landlord's working capital, positively related to the tenant's working capital, and not significantly related to the tenant's wealth. The authors conclude that financial constraints are more important than risk aversion in explaining the design of tenancy contracts. 


\section{Ackerberg and Botticini, J.P.E., 2002}

The possibility of endogenous matching between landlords' and tenants' unobservable characteristics is studied in this paper, by means of a historical data set from Renaissance Tuscany. Endogenous matching happens when there are reasons leading principals and agents to contract with each other. For instance, if tenants were heterogeneous in their level of risk aversion and plots differed in their level of riskiness, it could possibly be the case that less risk-averse tenants match with more risky plots. Since the rule governing the matches is unknown, using proxies for tenants' risk aversion and plots' risk is not enough to account for the endogeneity bias.

The paper uses geographical-based instruments to account for the endogeneity bias. The underlying assumption is that exogenous differences across regions affects the matching between risk and risk aversion, without affecting the contract design through other channels. Once this matching is taken into account, the authors find a positive correlation between the contract share and the tenant's wealth. Assuming that wealth is a proxy for risk aversion, this evidence supports insurance motives for share contracts.

\section{Dubois, J.D.E., 2002}

This paper develops a dynamic principal-agent model for agricultural tenancy where the optimal incentive power balances effort incentives, concerns about landquality maintenance, and risk sharing. In the model, land fertility is non-contractible and evolves over time. Moreover, contracts expire at the end of each season and long-term contracts are not enforceable.

The author derives testable predictions that relate contract choice and land value in environments where production effort can reduce land fertility due to land overuse. The analysis is implemented using data from rural areas of the Phillipines, collected by the International Food Policy Research Institute (Washington) and the Research Institute for Mindanao Culture (Xavier University, Phillipines).

Results reject the pure risk sharing model and the pure transaction costs approach. The trade-off between productivity and land fertility is supported by the data. Non-parametric estimation shows that the probability of leasing out a plot is inverse U-shaped with respect to the land's value. Among the leased plots, landlords choose more incentive-powered contracts for more valuable plots and for cropping patterns that are less likely to induce land overuse.

\section{Bandiera, Mimeo, 2001}

This article studies how crop characteristics affect the design of tenancy contracts, by using a historical data set collected between 1870 and 1980 in the province of Syracuse, Sicily. The empirical results indicate that: (i) the likelihood of share 
contracts is positively related to poor tenants and to crops whose productivity is sensitive to effort (such as vines and citrus trees); (ii) the most maintenance intensive crops (such as vines and citrus trees) tend to be leased under long-term contracts; (iii) there is a positive correlation between the contract length and the tenant's wealth for plots with low maintenance needs (such as wheat), and such a relation is non-significant for plots with high maintenance needs (such as vines, citrus, and other fruit tress).

\section{Pandey, Mimeo, 2001}

The effects of technology on the design of share contracts is studied through a database collected by the author in 1996 and 1998 in four villages of North India. The sample contains plot-level data on output and inputs of 270 randomly selected plots cultivated under sharecropping and ownership. The design of share contracts varies across villages in terms of the share of the output received by the tenant, the share of costs borne by them, and the frequency that contracts are repeated.

The author constructs different measures of noise, based on the standard deviation of the error term in a linear regression of output on different regressors (such as plot characteristics and dummy variables for the tenancy contract, year, village, and crop). Risk aversion is proxied by the tenant's castle. The author finds that the probability of having a share contract repeated is negatively related to the output noise. Moreover, sharecroppers' rewards are lower powered when the output is noisier.

\section{Braido, Mimeo, 2003b}

Two of the main difficulties in testing the relationship between risk and incentive power are that: (i) measures of risk based on output variability are affected by the farmer's actions, and (ii) risk aversion is heterogeneous across farmers. Braido (2003b) uses data from the ICRISAT's Village Level Studies, in India, to address these issues.

Exogenous risk is measured by the variability of the error term of a stochastic Cobb-Douglas production function. This measure of risk controls for variability caused by endogenously chosen inputs, cropping pattern, irrigation, etc. Moreover, risk-aversion heterogeneity is taken into account by means of a subsample of farmers who simultaneously own and sharecrop different plots (mixed tenants). Since in this subsample each household cultivates lands under different contracts, the design of these contracts must be related to characteristics of the land (such as risk), instead of characteristics of the household. The evidence indicates a positive relation between exogenous risk and incentive power, which does not support the risk-sharing argument for sharecropping. 


\section{$3 \quad$ Final Remarks and Policy Implications}

The insurance theory have lately received innumerous theoretical contributions, and the predictions of these theories have been tested against data from many different markets. Sharecropping is regarded as a classic example of insurance, and the empirical research in this area is mainly focused on moral hazard problems (as opposed to adverse selection issues that are usually studied in other insurance markets). In this essay, I discuss some papers that estimate the impact of different contracts on resource allocation and others testing among different theories used to explain the design of land-leasing contracts. This final section is intended to briefly comment on some policy implications derived from these papers.

There is a relative consensus among economists that better-defined property rights encourage investment decisions. The studies discussed in Section 1.1 suggest that land investments made by tenants are affected by tenure uncertainty. The paper by Besley (1985) shows that fear of expropriation would also affect landowners willingness to make land improvements. In terms of policy implications, it is widely believed that a reliable legal system (able to enforce contracts and to define property rights unambiguously) should positively impact land-leasing efficiency. Besides this, better-defined rights could also reduce the amount of non-utilized lands. In some developing countries, landholding is used as a store of value because public bonds and local currency are not always reliable mechanisms. Fearing land reforms, some of these investors prefer to keep the land unproductive instead of leasing it out to a tenant (see Berry and Cline, 1979, and Assunção, 2002). Therefore, improving the legal system to expand the set of feasible contracts can lead societies to more efficient allocations.

Section 1.2 discusses whether the lower incentive power of share contracts distorts the allocation of input resources. The evidence presented by most of the literature suggests share contracts induce lower productivity, but considering the arguments in Braido (2003a), one can still have doubts on this issue. This debate, however, generates no particular policy implication. Even if share contracts did induce lower productivity, they could still be desirable for solving the trade-off between incentives and risk sharing (see Stiglitz, 1974) or for alleviating soil exploitation (see Allen and Lueck, 1992 and 1993). A different conclusion would follow if share contracts were determined by other market imperfections, as analyzed in Section 2.

The discussion on the determinants of tenancy contracts is presented in Section 2. Many authors suggest that contract designs are determined by market imperfections, such as transaction costs (e.g., Allen and Lueck, 1992 and 1993) and credit-market imperfections (e.g., Laffont and Matoussi, 1995). In these cases, policies reducing transaction cost and promoting the development of capital markets are desirable.

Insurance markets improve the allocation of risk without ignoring effort incen- 
tives. In the past, microeconomic inefficiencies have been neglected in the debate on public policy. Harberger (1954) estimates that distortions associated with monopolistic behavior in U.S. industry would amount to approximately 0.1 percent of the U.S. GNP. A subsequent work, Harberger (1959), shows that this value would amount to about $15 \%$ of the GNP in the Chilean economy. Recently, the growth theory has suggested that differences in the total factor productivity account for most of the income inequality across countries (see Parente and Prescott, 2000). Microeconomic distortions, such as trade barriers, rent seeking, market power, and informational asymmetries are among the variables affecting a country's productivity. Therefore, applied research about asymmetric information in insurance markets belongs to a broad agenda on the field of economic development and has important welfare implications.

\section{References}

[1] Ackerberg, Daniel A. and Maristella Botticini. 2000. "The Choice of Agrarian Contracts in Early Renaissance Tuscany: Risk Sharing, Moral Hazard, or Capital Market Imperfections?" Explorations in Economic History, 37 (3) 241-257.

[2] Ackerberg, Daniel A. and Maristella Botticini. 2002. "Endogenous Matching and the Empirical Determinants of Contract Form." Journal of Political Economy, 110 (3), 564-591.

[3] Akerlof, A. George. 1970. "The Market for 'Lemons': Quality Uncertainty and the Market Mechanism." Quarterly Journal of Economics, 84 (3), 488-500.

[4] Allen, Douglas and Jean Lueck. 1992. "Contract Choice in Modern Agriculture: Cash Rent versus Cropshare." Journal of Law and Economics, 35 (2), 397-426.

[5] Allen, Douglas and Jean Lueck. 1993. "Transaction Costs and the Design of Cropshare Contracts." RAND Journal of Economics, 24 (1), 78-100.

[6] Assunção, Juliano J. 2002. "Eficiência Agrícola e Política Agrária no Brasil." Ph.D. Thesis, Pontifical Catholic University of Rio de Janeiro.

[7] Bandiera, Oriana. 2001. "On the Structure of Tenancy Contracts: Theory and Evidence from 19th Century Rural Sicily." Centre for Economic Policy Research (CEPR), Discussion Paper 3032.

[8] Bandiera, Oriana. 2002. "Land Tenure, Incentives and the Choice of Production Techniques in Rural Nicaragua." Mimeo, London School of Economics. 
[9] Banerjee, Abhijit, Paul Gertler, and Maitreesh Ghatak. 2002. "Empowerment and Efficiency: Tenancy Reform in West Bengal." Journal of Political Economy, 110 (2), 239-280.

[10] Berry, Albert and Willian R. Cline. 1979. Agrarian Structure and Productivity in Developing Countries. Johns Hopkins University Press, Baltimore.

[11] Besley, Timothy. 1995. "Property Rights and Investment Incentives: Theory and Evidence from Ghana." Journal of Political Economy, 103 (5), 903-937.

[12] Binswanger, Hans P., Klaus Deininger, and Gershon Feder. 1995. "Power, Distortions, Revolt, and Reform in Agricultural Land Relations." Handbook of Development Economics. Edited by Jere Behrman and T.N. Srinivasa, Elsevier, New York.

[13] Braido, Luis H.B. 2002. "Essays on Moral Hazard." Ph.D. Thesis, University of Chicago.

[14] Braido, Luis H.B. 2003a. "Evidence on the Incentive Properties of Share Contracts." EPGE Working Papers.

[15] Braido, Luis H.B. 2003b. "Evidence on the Relationship between Incentives and Exogenous Risk." EPGE Working Papers.

[16] Cheung, Steven N.S. 1969. The Theory of Share Tenancy. University of Chicago Press, Chicago.

[17] Cheung, Steven N.S. 2002. "Sharecropping." In Famous Fables of Economics: Myths of Market Failures. Edited by Daniel F. Spulber, Blackwell Publishers, Oxford, U.K.

[18] Cohen, Jon S. and Francesco L. Galassi. 1990. "Sharecropping and Productivity: 'Feudal Residues' in Italian Agriculture, 1911." Economic History Review, 43 (4), 646-656.

[19] Deininger, Klaus and Gershon Feder. 1997. "Land Institutions and Land Markets." Handbook of Agricultural Economics. Edited by Bruce L. Gardner and Gordon C. Rausser, Elsevier, New York.

[20] Dubois, Pierre. 2002. "Moral Hazard, Land Fertility and Sharecropping in a Rural Area of the Philippines." Journal of Development Economics, 68 (1), 35-64.

[21] Eswaran, Mukesh and Ashok Kotwal. 1985. "A Theory of Contractual Structure in Agriculture." American Economic Review, 75 (3), 352-367. 
[22] Green, Jerry R. and Nancy L. Stokey. 1983. "A Comparison of Tournaments and Contracts." Journal of Political Economy, 91 (3), 349-364.

[23] Grossman, Sanford J. and Oliver D. Hart. 1983. "An Analysis of the PrincipalAgent Problem." Econometrica, 51 (1), 7-45.

[24] Harberger, Arnold C. 1954. "Monopoly and Resource Allocation." American Economic Review Paper and Proceedings, 44 (2), 77-87.

[25] Harberger, Arnold C. 1959. "Using the Resources at Hand More Efficiently." American Economic Review, 49 (2), 134-146.

[26] Hodkinson, Stephen. 1992. "Sharecropping and Sparta's Economic Exploitation of the Helots." In Philolakôn Lakonian Studies in Honour of Hector W. Catling, Edited by J. Sanders, British School at Athens, Oxford, UK.

[27] Hoffman, Philip T. 1984. "The Economic Theory of Sharecropping in Early Modern France." Journal of Economic History, 44 (2), 309-319.

[28] Holmstrom, Bengt R. 1979. "Moral Hazard and Observability." Bell Journal of Economics, 10 (1), 74-91.

[29] Holmstrom, Bengt and Paul Milgrom. 1987. "Aggregation and Linearity in the Provision of Intertemporal Incentives." Econometrica, 55 (2), 303-328.

[30] Jacoby, Hanan G. and Ghazala Mansuri. 2002. "Incomplete Contracts and Investment: A Study of Land Tenancy in Pakistan." Mimeo, World Bank.

[31] Jodha, N.S. 1981. "Agricultural Tenancy: Fresh Evidence from Dryland Areas in India." Economic and Political Weekly, 16 (52), A118-A128.

[32] Johnson, D. Gale. 1950. "Resource Allocation under Share Contracts." Journal of Political Economy, 58 (2), 111-123.

[33] Laffont, Jean-Jacques and Mohamed S. Matoussi. 1995. "Moral Hazard, Financial Constraints and Sharecropping in El Oulja." Review of Economic Studies, $62(3), 381-399$.

[34] Lambert, Richard A. 1983. "Long-term Contracts and Moral Hazard." Bell Journal of Economics, 14 (2), 441-452.

[35] Lazear, Edward P. and Sherwin Rosen. 1981. "Rank-Order Tournaments as Optimum Labor Contracts." Journal of Political Economy, 89 (5), 841-864. 
[36] Marshall, Alfred. 1890. Principles of Economics. Edited by C. W. Guillebaud, Macmillan Company, London (1961).

[37] Marx, Karl. 1894. Capital. Edited by Frederick Engels, International Publishers, New York (1967).

[38] Mill, John Stuart. 1848. Principles of Political Economy. Edited by W. J. Ashley, Longmans Company, London (1936).

[39] Murrell, Peter. 1983. "The Economics of Sharing: A Transactional Cost Analysis of Contractual Choice in Farming." The Bell Journal of Economics, 14 (1), 283-293.

[40] Pandey, Priyanka. 2001. "Effects of Technology on Incentive Design of Share Contracts." Mimeo, Pennsylvania State University.

[41] Parente, Steven L. and Edward C. Prescott. 2000. Barriers to Riches. MTT Press, Cambridge.

[42] Prendergast, Canice. 2002. "The Tenuous Tradeoff between Risk and Incentives." Journal of Political Economy, 110 (5), 1035-1070.

[43] Quesnay, François. 1758. Tableau Économique. Macmillan Company Edition (1972).

[44] Radner, Roy. 1981. "Monitoring Cooperative Agreements in a Repeated Principal-Agent Relationship." Econometrica, 49 (5), 1127-1148.

[45] Radner, Roy. 1985. "Repeated Principal-Agent Games with Discounting." Econometrica, 53 (5), 1173-1198.

[46] Rao, C. H. Hanumantha. 1971. "Uncertainty, Entrepreneurship, and Sharecropping in India." Journal of Political Economy, 79 (3), 578-595.

[47] Rogerson, Willian P. 1985. "Repeated Moral Hazard." Econometrica, 53 (1), 69-76.

[48] Rothschild, Michael and Joseph E. Stiglitz. 1976. "Equilibrium in Competitive Insurance Markets: An Essay on the Economics of Imperfect Information." Quarterly Journal of Economics, 90 (4), 629-649.

[49] Rubinsteim, Abreu and Menahem E. Yaari. 1983. "Repeated Insurance Contracts and Moral Hazard." Journal of Economic Theory, 30 (1), 74-97. 
[50] Shaban, Radwan A. 1987. "Testing Between Competing Models of Sharecropping." Journal of Political Economy, 95 (5), 893-920.

[51] Smith, Adam. 1776. An Inquiry into the Nature and Causes of the Wealth of Nations. Edited by Edwin Cannan, University of Chicago Press, Chicago (1976).

[52] Spear, Stephen E. and Sanjay Srivatava. 1987. "On Repeated Moral Hazard with Discounting." Review of Economic Studies, 54 (4), 599-617.

[53] Spence, A. Michael. 1973. "Job Market Signaling." Quarterly Journal of Economics, 87 (3), 355-374.

[54] Stiglitz, Joseph E. 1974. "Incentives and Risk Sharing in Sharecropping." Review of Economic Studies, 41 (2), 219-255.

[55] Williamson, Oliver E. 1979. "Transaction-Cost Economics: The Governance of Contractual Relations." Journal of Law and Economics, 22 (2), 233-261. 


\section{CESifo Working Paper Series}

(for full list see www.cesifo.de)

1031 Ivar Ekeland, James J. Heckman, and Lars Nesheim, Identifcation and Estimation of Hedonic Models, September 2003

1032 Kjetil Bjorvatn and Alexander W. Cappelen, Decentralization and the Fate of Minorities, September 2003

1033 Lars-Erik Borge and Jørn Rattsø, The Relationships Between Costs and User Charges: The Case of a Norwegian Utility Service, September 2003

1034 Maureen Were and Nancy N. Nafula, An Assessment of the Impact of HIV/AIDS on Economic Growth: The Case of Kenya, September 2003

1035 A. Lans Bovenberg, Tax Policy and Labor Market Performance, September 2003

1036 Peter Birch Sørensen, Neutral Taxation of Shareholder Income: A Norwegian Tax Reform Proposal, September 2003

1037 Roberta Dessi and Sheilagh Ogilvie, Social Capital and Collusion: The Case of Merchant Guilds, September 2003

1038 Alessandra Casarico and Carlo Devillanova, Capital-skill Complementarity and the Redistributive Effects of Social Security Reform, September 2003

1039 Assaf Razin and Efraim Sadka, Privatizing Social Security Under Balanced-Budget Constraints: A Political-Economy Approach, September 2003

1040 Michele Moretto, Paolo M. Panteghini, and Carlo Scarpa, Investment Size and Firm's Value under Profit Sharing Regulation, September 2003

1041 A. Lans Bovenberg and Peter Birch Sørensen, Improving the Equity-Efficiency Tradeoff: Mandatory Savings Accounts for Social Insurance, September 2003

1042 Bas van Aarle, Harry Garretsen, and Florence Huart, Transatlantic Monetary and Fiscal Policy Interaction, September 2003

1043 Jerome L. Stein, Stochastic Optimal Control Modeling of Debt Crises, September 2003

1044 Thomas Stratmann, Tainted Money? Contribution Limits and the Effectiveness of Campaign Spending, September 2003

1045 Marianna Grimaldi and Paul De Grauwe, Bubbling and Crashing Exchange Rates, September 2003 
1046 Assar Lindbeck and Dennis J. Snower, The Firm as a Pool of Factor Complementarities, September 2003

1047 Volker Grossmann, Firm Size and Diversification: Asymmetric Multiproduct Firms under Cournot Competition, September 2003

1048 Dan Anderberg, Insiders, Outsiders, and the Underground Economy, October 2003

1049 Jose Apesteguia, Steffen Huck and Jörg Oechssler, Imitation - Theory and Experimental Evidence, October 2003

1050 G. Abío, G. Mahieu and C. Patxot, On the Optimality of PAYG Pension Systems in an Endogenous Fertility Setting, October 2003

1051 Carlos Fonseca Marinheiro, Output Smoothing in EMU and OECD: Can We Forego Government Contribution? A Risk Sharing Approach, October 2003

1052 Olivier Bargain and Nicolas Moreau, Is the Collective Model of Labor Supply Useful for Tax Policy Analysis? A Simulation Exercise, October 2003

1053 Michael Artis, Is there a European Business Cycle?, October 2003

1054 Martin R. West and Ludger Wößmann, Which School Systems Sort Weaker Students into Smaller Classes? International Evidence, October 2003

1055 Annette Alstadsaeter, Income Tax, Consumption Value of Education, and the Choice of Educational Type, October 2003

1056 Ansgar Belke and Ralph Setzer, Exchange Rate Volatility and Employment Growth: Empirical Evidence from the CEE Economies, October 2003

1057 Carsten Hefeker, Structural Reforms and the Enlargement of Monetary Union, October 2003

1058 Henning Bohn and Charles Stuart, Voting and Nonlinear Taxes in a Stylized Representative Democracy, October 2003

1059 Philippe Choné, David le Blanc and Isabelle Robert-Bobée, Female Labor Supply and Child Care in France, October 2003

1060 V. Anton Muscatelli, Patrizio Tirelli and Carmine Trecroci, Fiscal and Monetary Policy Interactions: Empirical Evidence and Optimal Policy Using a Structural New Keynesian Model, October 2003

1061 Helmuth Cremer and Pierre Pestieau, Wealth Transfer Taxation: A Survey, October 2003

1062 Henning Bohn, Will Social Security and Medicare Remain Viable as the U.S. Population is Aging? An Update, October 2003

1063 James M. Malcomson, Health Service Gatekeepers, October 2003 
1064 Jakob von Weizsäcker, The Hayek Pension: An efficient minimum pension to complement the welfare state, October 2003

1065 Joerg Baten, Creating Firms for a New Century: Determinants of Firm Creation around 1900, October 2003

1066 Christian Keuschnigg, Public Policy and Venture Capital Backed Innovation, October 2003

1067 Thomas von Ungern-Sternberg, State Intervention on the Market for Natural Damage Insurance in Europe, October 2003

1068 Mark V. Pauly, Time, Risk, Precommitment, and Adverse Selection in Competitive Insurance Markets, October 2003

1069 Wolfgang Ochel, Decentralising Wage Bargaining in Germany - A Way to Increase Employment?, November 2003

1070 Jay Pil Choi, Patent Pools and Cross-Licensing in the Shadow of Patent Litigation, November 2003

1071 Martin Peitz and Patrick Waelbroeck, Piracy of Digital Products: A Critical Review of the Economics Literature, November 2003

1072 George Economides, Jim Malley, Apostolis Philippopoulos, and Ulrich Woitek, Electoral Uncertainty, Fiscal Policies \& Growth: Theory and Evidence from Germany, the UK and the US, November 2003

1073 Robert S. Chirinko and Julie Ann Elston, Finance, Control, and Profitability: The Influence of German Banks, November 2003

1074 Wolfgang Eggert and Martin Kolmar, The Taxation of Financial Capital under Asymmetric Information and the Tax-Competition Paradox, November 2003

1075 Amihai Glazer, Vesa Kanniainen, and Panu Poutvaara, Income Taxes, Property Values, and Migration, November 2003

1076 Jonas Agell, Why are Small Firms Different? Managers’ Views, November 2003

1077 Rafael Lalive, Social Interactions in Unemployment, November 2003

1078 Jean Pisani-Ferry, The Surprising French Employment Performance: What Lessons?, November 2003

1079 Josef Falkinger, Attention, Economies, November 2003

1080 Andreas Haufler and Michael Pflüger, Market Structure and the Taxation of International Trade, November 2003

1081 Jonas Agell and Helge Bennmarker, Endogenous Wage Rigidity, November 2003 
1082 Fwu-Ranq Chang, On the Elasticities of Harvesting Rules, November 2003

1083 Lars P. Feld and Gebhard Kirchgässner, The Role of Direct Democracy in the European Union, November 2003

1084 Helge Berger, Jakob de Haan and Robert Inklaar, Restructuring the ECB, November 2003

1085 Lorenzo Forni and Raffaela Giordano, Employment in the Public Sector, November 2003

1086 Ann-Sofie Kolm and Birthe Larsen, Wages, Unemployment, and the Underground Economy, November 2003

1087 Lars P. Feld, Gebhard Kirchgässner, and Christoph A. Schaltegger, Decentralized Taxation and the Size of Government: Evidence from Swiss State and Local Governments, November 2003

1088 Arno Riedl and Frans van Winden, Input Versus Output Taxation in an Experimental International Economy, November 2003

1089 Nikolas Müller-Plantenberg, Japan’s Imbalance of Payments, November 2003

1090 Jan K. Brueckner, Transport Subsidies, System Choice, and Urban Sprawl, November 2003

1091 Herwig Immervoll and Cathal O'Donoghue, Employment Transitions in 13 European Countries. Levels, Distributions and Determining Factors of Net Replacement Rates, November 2003

1092 Nabil I. Al-Najjar, Luca Anderlini \& Leonardo Felli, Undescribable Events, November 2003

1093 Jakob de Haan, Helge Berger and David-Jan Jansen, The End of the Stability and Growth Pact?, December 2003

1094 Christian Keuschnigg and Soren Bo Nielsen, Taxes and Venture Capital Support, December 2003

1095 Josse Delfgaauw and Robert Dur, From Public Monopsony to Competitive Market. More Efficiency but Higher Prices, December 2003

1096 Clemens Fuest and Thomas Hemmelgarn, Corporate Tax Policy, Foreign Firm Ownership and Thin Capitalization, December 2003

1097 Laszlo Goerke, Tax Progressivity and Tax Evasion, December 2003

1098 Luis H. B. Braido, Insurance and Incentives in Sharecropping, December 2003 